\title{
PHYSICAL PROPERTIES OF A RED-YELLOW LATOSOL AND PRODUCTIVITY OF A SIGNALGRASS PASTURE FERTILIZED WITH INCREASING NITROGEN DOSES ${ }^{(1)}$
}

\author{
Igor Alexandre de Souza ${ }^{(2)}$, Karina Guimarães Ribeiro ${ }^{(3)}$, Wellington Willian Rocha ${ }^{(4)}$, \\ Odilon Gomes Pereira ${ }^{(5)} \&$ Paulo Roberto Cecon ${ }^{(6)}$
}

\begin{abstract}
SUMMARY
The physical properties and fertility of the soil are important factors in the formation and establishment of pasture. Changes in physical properties affect the movement of water, air, nutrients and roots, which, in turn, affect the productivity and longevity of pastures. The objective of this study was to evaluate the physical properties of the soil and the dry matter yield of a pasture with signalgrass cv. Basilisk (Brachiaria decumbens cv. Basilisk), fertilized with increasing nitrogen doses $(\mathrm{N})$, on a dystrophic Red-Yellow Latosol. The experiment was conducted on the Fazenda Rio Manso of the Universidade Federal dos Vales do Jequitinhonha e Mucuri, in Couto de Magalhães de Minas, State of Minas Gerais, Brazil. To evaluate the annual forage yield, a split plot scheme in a randomized block design with four replications was used, with $\mathrm{N}$ doses $(0,50,100,150$, and $200 \mathrm{~kg} / \mathrm{ha} / \mathrm{year})$ in the plots and growing seasons (first and second) in the subplots. For soil evaluation, a split plot scheme was used with $N$ doses $(0,25,50,75$ and $100 \mathrm{~kg} / \mathrm{ha} / \mathrm{cut})$ in the plots and three sampling times (prior to the experiment, at the end of the first growing season and at the end of the second growing season) in the subplots in a randomized block design with four replications. This analysis was performed separately at two soil depths (0-3 and 10-13 cm). Forage samples were analyzed for the annual dry matter yield (DMY), and soil samples were analyzed for pre-consolidation pressure $(\sigma p)$, initial soil bulk density (Bd), total pore volume (TPV) and void index (Vd). Higher nitrogen doses increased the dry matter yield of signalgrass pasture and
\end{abstract}

(1) Part of the Master's Thesis of the first author, submitted at Universidade Federal dos Vales do Jequitinhonha e Mucuri UFVJM. Received for publication on October 4, 2012 and approved on August 30, 2013.

(2) Zootechnician, Master student in Animal Science, UFVJM. Rodovia MGT 367, km 583, n 5000, Alto da Jacuba. CEP: 39.100000 Diamantina (MG), Brazil. E-mail: igordadim@hotmail.com

(3) Adjunct Professor, Department of Animal Science - DAS, UFVJM. E-mail: karina_ufvjm@yahoo.com.br

(4) Associate Co-advisor Professor, Department of Agronomy, UFVJM. E-mail: wwillian@ufvjm.edu.br

(5) Associate Professor, Department of Animal Science, Universidade Federal de Viçosa - UFV. Av. P. H. Rolfs, s/n. CEP $36570-900$ Viçosa (MG), Brazil. E-mail: odilon@ufv.br

(6) Associate Professor, Department of Informatics, UFV. E-mail: cecon@ufv.br 
the pre-consolidation pressure of the soil. The total pore volume and void index decreased, and the initial soil bulk density increased, though without promoting soil compaction.

Index terms: pre-consolidation pressure, soil bulk density, total pore volume, void index.

\title{
RESUMO: ATRIBUTOS FÍSICOS DE UM LATOSSOLO VERMELHO-AMARELO E PRODUTIVIDADE DE UM PASTO DE CAPIM-BRAQUIÁRIA SOB DOSES CRESCENTES DE NITROGENNIO
}

\begin{abstract}
Os atributos físicos e a fertilidade do solo são importantes fatores envolvidos na formação e no estabelecimento de pastagens. Mudanças nos atributos físicos interferem na movimentação de água, ar e nutrientes e crescimento de raízes, o que reflete na produtividade e longevidade dos pastos. Assim, objetivou-se avaliar os atributos físicos do solo e a produtividade de massa de matéria seca de um pasto de capim-braquiária cv. Basilisk (Brachiaria decumbens cv. Basilisk), sob doses crescentes de nitrogênio, em um Latossolo Vermelho-Amarelo distrófico. $O$ experimento foi conduzido na Fazenda Rio Manso da Universidade Federal dos Vales do Jequitinhonha e Mucuri /UFVJM, na cidade de Couto de Magalhães de Minas, MG. Para a avaliação da produtividade anual da forrageira, utilizou-se o esquema de parcelas subdivididas no delineamento em blocos casualizados, com quatro repetições, com as doses de nitrogênio (0, 50, 100, 150 e $200 \mathrm{~kg} / \mathrm{ha} /$ ano) nas parcelas e os anos agrícolas $\left(1^{\circ}\right.$ e $\left.2^{\circ}\right)$, dispostos nas subparcelas. Para a avaliação do solo, utilizou-se o esquema de parcelas subdivididas, com as doses de nitrogênio $(0,25,50,75$ e $100 \mathrm{~kg} / \mathrm{ha} / \mathrm{corte})$ nas parcelas e os três momentos de amostragem (antes do início do experimento, ao final do $1^{\circ}$ ano agrícola e ao final do $2^{\circ}$ ano agrícola) nas subparcelas, no delineamento em blocos casualizados, com quatro repetições. Essa análise foi realizada separadamente, para as profundidades de coleta de solo de 0-3 e 10-13 cm. Nas amostras da planta forrageira, foi analisada a produtividade anual de massa de matéria de seca (PMS); nas amostras de solo, foram analisados pressão de pré-consolidação ( $\sigma p)$, densidade do solo inicial (DS), volume total de poros (VTP) e indice de vazios (Ie). Concluiu-se que doses mais elevadas de nitrogênio aumentaram a produtividade de matéria seca do pasto de capim-braquíaria, assim como a pressão de pré-consolidação do solo. O volume total de poros e o indice de vazios diminuíram e a densidade do solo inicial aumentou, mas não a ponto de promover a compactação do solo.
\end{abstract}

Termos de indexação: densidade do solo, índice de vazios, pressão de pré-consolidação, volume total de poros.

\section{INTRODUCTION}

The physical properties and fertility of the soil are important factors involved in the formation and establishment of pasture. Changes in physical properties affect the movement of water, air, nutrients and roots growth, which, in turn, influence the productivity and longevity of pastures.

The currently used indices of herd productivity are considered unsatisfactory by most producers. The low productivity and quality of the forages and the degradation of large pasture areas due to improper management of grazing and fertilization are partly responsible for this situation (Costa et al., 2008).

Soil compaction, characterized by the reduction of the porous space under external soil pressure, can be a major problem in heavily mechanized and/or trampled areas and is one of the key factors associated with soil degradation (Kondo \& Dias Junior, 1999; Mosaddeghi et al., 2007; Carvalho et al., 2010; Pires et al., 2012). Soil compaction can result in a reduction in the productivity and longevity of pastures (Imhoff et al., 2000) and accelerate erosion processes (Oliveira et al., 2004).

The soil compression curve is a parameter that can facilitate the analysis of the compaction process. This curve relates the void index to the logarithm of the pressure applied to the soil and generates the preconsolidation pressure $(\sigma p)$, an estimate of the capacity of the soil to support a given load (Dias Junior \& Pierce, 1996). The soil compression curve divides the deformation of the soil structure into recoverable and non-recoverable regions that are elastic and plastic, respectively. If the pressure applied to the soil is in the recoverable region (elastic), there will be no additional soil compaction; if the pressure is applied in the non-recoverable (plastic) region, there will be permanent deformation of the soil structure, causing additional compaction. The pressure that divides these two regions (recoverable and non-recoverable) is called the preconsolidation pressure (Dias Junior \& Pierce, 1996). 
Based on these considerations, the aim of this work was to evaluate the physical properties of the soil (preconsolidation pressure, initial soil bulk density, total pore volume and void index) and the dry matter productivity of a brachiaria cv. Basilisk (Brachiaria decumbens cv. Basilisk) grass pasture fertilized with increasing nitrogen doses on a dystrophic Red-Yellow Latosol.

\section{MATERIAL AND METHODS}

The experiment was conducted on the Fazenda Rio Manso in the experimental unit of the Universidade Federal dos Vales do Jequitinhonha e Mucuri (UFVJM) in the municipality of Couto de Magalhães de Minas, State of Minas Gerais, Brazil $\left(18^{\circ} 4^{\prime} 25.53 \mathrm{~S}, 43^{\circ}\right.$ $28^{\prime} 16^{\prime \prime} \mathrm{W}$, at $756 \mathrm{~m}$ asl). The regional climate is humid subtropical (Cwa) according to the Köppen-Geiger classification. The average annual temperature is $23.8^{\circ} \mathrm{C}$ and rainfall $1,404 \mathrm{~mm} /$ year. The accumulated rainfall in the first and second growing seasons of the experimental period was 676.9 and $631.1 \mathrm{~mm}$, respectively.

Soil samples were collected in the layers 0-10 and $10-20 \mathrm{~cm}$, as is common in analyses of pastures with forage grasses. The samples were analyzed at the Laboratory of Soil Fertility of UFVJM. The soil, classified as dystrophic Red-Yellow Latosol (Embrapa, 2006), had a clayey texture with low natural fertility (Table 1).

Table 1. Chemical and physical characteristics of soil samples collected in the two layers prior to the experiment

\begin{tabular}{lcc}
\hline \multirow{2}{*}{ Attribute } & \multicolumn{2}{c}{ Soil layer } \\
\cline { 2 - 3 } & $\mathbf{0 - 1 0 ~} \mathbf{~ c m}$ & $\mathbf{1 0 - 2 0 ~} \mathbf{~ c m}$ \\
\hline $\mathrm{pH}\left(\mathrm{H}_{2} \mathrm{O}\right)$ & 5.40 & 5.50 \\
Organic matter $\left(\mathrm{dag} \mathrm{kg}^{-1}\right)$ & 1.70 & 1.00 \\
$\mathrm{P}\left(\mathrm{mg} \mathrm{dm}^{-3}\right)$ & 1.63 & 1.03 \\
$\mathrm{~K}\left(\mathrm{mg} \mathrm{dm}^{-3}\right)$ & 49.0 & 30.0 \\
$\mathrm{Ca}^{2+}\left(\mathrm{cmol}_{\mathrm{c}} \mathrm{dm}^{-3}\right)$ & 1.34 & 1.02 \\
$\mathrm{Mg}^{2+}\left(\mathrm{cmol}_{\mathrm{c}} \mathrm{dm}^{-3}\right)$ & 0.48 & 0.60 \\
$\mathrm{Al}^{3+}\left(\mathrm{cmol}_{\mathrm{c}} \mathrm{dm}^{-3}\right)$ & 0.50 & 0.40 \\
$\mathrm{H}+\mathrm{Al}\left(\mathrm{cmol}_{\mathrm{c}} \mathrm{dm}^{-3}\right)$ & 7.30 & 6.50 \\
$\mathrm{BS}\left(\mathrm{cmol}_{\mathrm{c}} \mathrm{dm}^{-3}\right)$ & 1.95 & 1.70 \\
$\mathrm{t}\left(\mathrm{cmol} \mathrm{dm}^{-3}\right)$ & 2.45 & 2.10 \\
$\mathrm{~T}\left(\mathrm{cmol}_{\mathrm{c} \mathrm{dm}}{ }^{-3}\right)$ & 9.25 & 8.20 \\
$\mathrm{~V}(\%)$ & 20.0 & 19.0 \\
$\mathrm{~m}(\%)$ & 21.0 & 21.0 \\
$\mathrm{Sand}\left(\mathrm{g} \mathrm{kg}^{-1}\right)$ & 430.0 & 430.0 \\
$\mathrm{Silt}\left(\mathrm{g} \mathrm{kg}^{-1}\right)$ & 150.0 & 130.0 \\
$\mathrm{Clay}\left(\mathrm{g} \mathrm{kg}^{-1}\right)$ & 420.0 & 440.0 \\
$\mathrm{Bd}\left(\mathrm{Mg} \mathrm{m}^{-3}\right)$ & 1.34 & 1.34 \\
$\mathrm{Pd}\left(\mathrm{Mg} \mathrm{m}^{-3)}\right.$ & 2.63 & 2.63 \\
$\mathrm{TPV}\left(\mathrm{m}^{3} \mathrm{~m}^{-3}\right)$ & 0.50 & 0.50 \\
\hline
\end{tabular}

The experiment was conducted in an area of degraded signalgrass (Brachiaria decumbens cv. Basilisk) where pasture had been planted approximately 10 years ago; the area had low dry matter productivity and considerable weed infestation. In this period, the grazing pressure was not controlled and no fertilization was applied. The weed control in the experimental area consisted of hand weeding.

To assess the dry matter yield (DMY) of the signalgrass, data were analyzed in a split plot scheme with different $\mathrm{N}$ doses $(0,50,100,150$ and $200 \mathrm{~kg} / \mathrm{ha} /$ year) in plots and agricultural years (first and second) in subplots using a randomized block design with four replications.

To standardize the plants in all plots, the plants were cut at a height of $10 \mathrm{~cm}$ with a motor-driven backpack mower on December 13, 2010. The cut material was removed with a rake and all plots in the cut area were fertilized with $100 \mathrm{~kg} / \mathrm{ha} \mathrm{P}_{2} \mathrm{O}_{5}$ and $75 \mathrm{~kg} / \mathrm{ha} \mathrm{K}_{2} \mathrm{O}$ based on a soil chemical analysis; $\mathrm{N}$ doses $(0,25,50,75$ and $100 \mathrm{~kg} / \mathrm{ha} / \mathrm{cut})$ in the form of simple superphosphate, potassium chloride and ammonium sulfate were also added. Plants were harvested after approximately 42 days of regrowth.

The plants were first cut on January 24, 2011 and $\mathrm{N}$ doses were reapplied with $75 \mathrm{~kg} / \mathrm{ha} \mathrm{K}_{2} \mathrm{O}$; on April 14,2011 , the second cut was performed and $\mathrm{N}$ and $\mathrm{K}$ doses were reapplied; on April 30, 2011, the third cut was performed but not evaluated due to accidental grazing on the plots. After each cut, the cut material was removed from the plots. The DMY of the first cut was added to the DMY of the second cut to evaluate overall DMY in the first growing season. On August 10,2011 , dolomitic limestone was applied to raise the soil base saturation to $45 \%$, as indicated by a soil analysis conducted after the first study year (Table 2).

To further standardize the plants in all plots, the plants were cut at a height of $10 \mathrm{~cm}$ with a backpack mower on October 31, 2011. The cut material was removed using a rake and all plots in the cut area were fertilized with $75 \mathrm{~kg} / \mathrm{ha} \mathrm{K}_{2} \mathrm{O}$ and $\mathrm{S}$ ! of the total $\mathrm{N}$ doses used in the treatments $(0,25,50,75$ and $100 \mathrm{~kg} / \mathrm{ha} / \mathrm{cut}$ ); the same sources of chemicals as in the first growing season were used.

On August 12, 2011, the plants were cut for the fourth time but not evaluated because of a leafhopper infestation; doses of $\mathrm{N}$ fertilizer and $75 \mathrm{~kg} / \mathrm{ha} \mathrm{K}_{2} \mathrm{O}$ were reapplied. On January 16, 2012, the fifth cut of the plants was performed and $\mathrm{N}$ and $\mathrm{K}$ were reapplied; on February 27, 2012, the sixth cut was performed without fertilizer applications. After each cut, the cut material was removed from the plots. The DMY of the fifth was added to the DMY of the sixth cut to evaluate the overall DMY of the second growing season.

The forage was sampled from a square area of $1.0 \mathrm{~m}^{2}$ at the center of each plot; the plants were handcut with a scythe to a height of $10 \mathrm{~cm}$. To prepare air- 
Table 2. Chemical characteristics of soil from the 0-10 cm layer at each nitrogen dose at the first growing season

\begin{tabular}{|c|c|c|c|c|c|c|c|c|c|c|c|c|c|}
\hline N dose & pH & OM & $\mathbf{P}$ & $\mathbf{K}$ & $\mathrm{Ca}^{2+}$ & $\mathrm{Mg}^{2+}$ & $\mathrm{Al}^{3+}$ & $\mathrm{H}+\mathrm{Al}$ & SB & $\mathrm{t}$ & $\mathbf{T}$ & $\mathrm{V}$ & $\mathbf{m}$ \\
\hline $\mathrm{kg} \mathrm{ha}^{-1}$ year $^{-1}$ & \multicolumn{4}{|c|}{ dag $\mathrm{kg}^{-1}$} & \multicolumn{7}{|c|}{$-\mathrm{cmol}_{\mathrm{c}} \mathrm{dm}^{-3}-$} & \multicolumn{2}{|c|}{$\%$} \\
\hline 0 & 5.6 & 2.8 & 8.74 & 188.4 & 1.4 & 0.7 & 0.30 & 5.8 & 2.58 & 2.88 & 8.38 & 31 & 10 \\
\hline 25 & 5.2 & 2.9 & 7.07 & 149.2 & 1.5 & 0.7 & 0.40 & 6.5 & 2.58 & 2.98 & 9.08 & 28 & 13 \\
\hline 50 & 5.0 & 2.8 & 5.91 & 114.2 & 1.2 & 1.0 & 0.50 & 6.5 & 2.49 & 2.99 & 8.99 & 28 & 17 \\
\hline 75 & 5.1 & 2.9 & 7.53 & 155.4 & 1.2 & 0.7 & 0.50 & 9.1 & 2.30 & 2.80 & 1.40 & 20 & 18 \\
\hline 100 & 4.8 & 2.6 & 6.53 & 135.0 & 1.0 & 0.3 & 0.96 & 9.1 & 1.65 & 2.61 & 10.75 & 15 & 37 \\
\hline
\end{tabular}

dried fine earth for evaluation, plant samples were weighed and dried in a forced-air oven at $55{ }^{\circ} \mathrm{C}$ to constant weight; samples were then ground in a Willey mill with a $1 \mathrm{~mm}$ sieve and oven-dried at $105^{\circ} \mathrm{C}$ to adjust the green matter yield to the dry matter yield.

To evaluate the soil, a split plot scheme was used with $\mathrm{N}$ doses $(0,25,50,75$ and $100 \mathrm{~kg} / \mathrm{ha} / \mathrm{cut})$ in the plots and three sampling times (prior to the experiment, at the end of the first growing season and at the end of the second growing season) in the subplots in a randomized block design with four replications.

Disturbed and undisturbed soil samples were collected prior to the experiment, at the end of the first growing season (May 14, 2011) and at the end of the second growing season (March 03, 2012). Disturbed samples were collected for soil chemical and physical analysis before treatment application (Table 1). The undisturbed soil samples were collected for a compression test with an Uhland sampler with aluminum rings (inner diameter $63.5 \mathrm{~mm}$, height $25 \mathrm{~mm}$ ). One sample was collected from a $9 \mathrm{~m}^{2}$ area of each of the 20 plots and each layer (0-3 and $10-13 \mathrm{~cm})$.

Fifteen undisturbed reference samples were collected from native woodlands with the same soil class near the experimental area; the soils were randomly sampled in each layer $(0-3$ and $10-13 \mathrm{~cm})$ with the same sampling rings as for the plots.

The particle density $(\mathrm{Pd})$ was analyzed with the volumetric flask method and the texture characterized (Table 3) with the pipette method (Embrapa, 1997). The total pore volume (TPV) was calculated by the equation: $\mathrm{TPV}=1-(\mathrm{SBd} / \mathrm{Pd})$.

Samples from the experimental area were subjected to a tension of water retention of $-6 \mathrm{kPa}$, and samples from the native area to water tensions of $-2,-4,-6,-8$ and $-10 \mathrm{kPa}$. To determine the load-bearing capacity of the soil (Dias Junior, 1994) after stabilization of the tension of water retention, the samples were subjected to compressibility tests to determine the preconsolidation $(\sigma p)$ pressure values for the experimental area and to develop a structural sustainability model as a function of the pre-consolidation pressure $(\sigma p)$ versus moisture in the woodland area.
Table 3. Textural characterization of soil and particle density (Pd)

\begin{tabular}{ccrcc}
\hline Depth & Sand & Silt & Clay & Pd \\
\hline \multirow{2}{*}{$\mathrm{cm}$} & & $\mathrm{g} \mathrm{kg}^{-1}$ & & $\mathrm{Mg} \mathrm{m}^{-3}$ \\
$0-3$ & 430 & 150 & 420 & 2.63 \\
$10-13$ & 430 & 130 & 440 & 2.63 \\
\hline
\end{tabular}

Loads were applied to each sample (body of evidence) by means of compressed air in a compression cell using a consolidometer (model CNTA-IHM/BR001/07) in the following order: $25 ; 50 ; 100 ; 200 ; 400$; 800 and $1,600 \mathrm{kPa}$. Each pressure was applied until $90 \%$ of the maximum deformation was reached, according to the method described by Holtz \& Kovacs (1981) and modified by Dias Junior (1994); once $90 \%$ maximum deformation was achieved, a new pressure was applied. After the test was completed, samples were dried at $105{ }^{\circ} \mathrm{C}$ to constant weight to determine gravimetric moisture (Embrapa, 1997).

Compression curves were obtained and the preconsolidation pressure $(\sigma p)$, void index $(V d)$ and initial soil bulk density (Bd) determined for each sample, according to the method proposed by Casagrande (1936) and modified by Dias Junior \& Pierce (1995).

Data were subjected to variance and regression analyses using the statistical program SAEG 9.1 (SAEG, 2007).

\section{RESULTS AND DISCUSSION}

The results of dry matter yield for signalgrass are shown in table 4 . The effect of the interaction between $\mathrm{N}$ doses and year on the dry matter production (DMY) of signalgrass was not significant ( $p>0.05)$; however, the $\mathrm{N}$ doses $(\mathrm{p}<0.01)$ and year $(\mathrm{p}<0.01)$ had significant effects on DMY. The DMY ranged from $2,788.32$ to $7,611.62 \mathrm{~kg} / \mathrm{ha} /$ year for $\mathrm{N}$ doses of 0 to $200 \mathrm{~kg} / \mathrm{ha} /$ year. The DMY was higher in the second year $(5,257.7 \mathrm{~kg} / \mathrm{ha})$ than in the first year $(2,729.8 \mathrm{~kg} / \mathrm{ha})$. The recovery of signalgrass with nitrogen fertilization over time was evident, and DMY had increased significantly within only two years. 
The soil chemical characteristics were analyzed for each $\mathrm{N}$ fertilizer dose at the end of the experiment (Table 5). The highest $\mathrm{N}$ fertilizer dose reduced the soil $\mathrm{pH}$ to 4.8 ; this reduction can be attributed to the release of $\mathrm{H}^{+}$ions in the reaction of ammonium sulfate with the soil. The $\mathrm{Ca}^{2+}$ and $\mathrm{Mg}^{2+}$ levels were low, most likely due to the lack of limestone incorporation before the beginning of the second study year. Because $\mathrm{K}$ levels were high, the dose of $\mathrm{K}_{2} \mathrm{O}$ ( $75 \mathrm{~kg} / \mathrm{ha} / \mathrm{cut}$ ) applied with the $\mathrm{N}$ fertilizer could have been lowered. Reductions in the P levels were observed; these reductions may be related to a higher extraction of soil $\mathrm{P}$ in the second year resulting from the higher production of plant dry matter (Table 4). The base saturation was below $45 \%$ at the end of the second study year, since soil sampling was performed only five months after surface liming.

The pre-consolidation pressures $(\sigma p)$, initial bulk density (Bd), total pore volumes (TPV) and void indices (Vd) (shown in table 6) were assessed under five $\mathrm{N}$ doses in three evaluations and in the layers 0-3 and $10-13 \mathrm{~cm}$, respectively.

The interaction between $\mathrm{N}$ doses and sampling times had no significant effect ( $p>0.05)$ on any of the studied variables. The pre-consolidation pressure $(\sigma p)$ was affected by nitrogen doses $(p<0.05)$ and by sampling times $(p<0.01)$ in the layer $0-3 \mathrm{~cm}$; however, in the layer 10-13 cm, $\sigma p$ was affected only by sampling time $(\mathrm{p}<0.01)$. Similarly, the initial soil bulk density (Bd), total pore volume (TPV) and void indices $(\mathrm{Vd})$ were only affected by sampling time $(\mathrm{p}<0.01)$ at both depths (0-3 and 10-13 cm) (Table 6).

No model could be fitted to the $\sigma p$ values as a function of $\mathrm{N}$ doses, as demonstrated by the very low coefficients of determination; therefore the average estimated values of $\sigma p, \mathrm{Bd}$, TPV and Ie at the five $\mathrm{N}$ doses in the $0-3 \mathrm{~cm}$ layer were $241.14 \mathrm{kPa}$; $1.30 \mathrm{Mg} \mathrm{m}^{-3} ; 0.49 \mathrm{~m}^{3} \mathrm{~m}^{-3}$ and 0.97 , respectively, and $261.66 \mathrm{kPa} ; 1.35 \mathrm{Mg} \mathrm{m}^{-3} ; 0.49 \mathrm{~m}^{3} \mathrm{~m}^{-3}$ and 0.95 , respectively, in the $10-13 \mathrm{~cm}$ layer.

In the layer 0-3 cm (Table 6), the values of preconsolidation pressure $(\sigma p$ - an indicator of the maximum pressure a soil can support) were 269.74 and $282.52 \mathrm{kPa}$ in the second and third evaluation, respectively; these values were not significantly different, but were higher than the value obtained in the first evaluation $(171.15 \mathrm{kPa})$. The behavior of $\sigma p$ in the layer 10-13 cm (Table 6) was similar to that in the surface layer; in fact, in the surface layer, $\sigma p$ values were 308.1 and $288.6 \mathrm{kPa}$ in the second and third evaluations, respectively. These values were not significantly different from each other, but were higher than the value observed in the first evaluation $(176.6 \mathrm{kPa})$. These values were similar to those obtained by Kondo \& Dias Junior (1999) in a Latosol under pasture.

The increase in pre-consolidation pressure over the experimental period was related to the recovery of the load-bearing capacity of the soil; after the experiment, the soil could support higher loads of animal trampling without leading to compaction, which would have been detrimental to pasture productivity. However, loads above the pre-consolidation pressure $(\sigma p)$ would certainly increase compaction, especially at similar soil moisture levels to those in this study. It is important to stress that these tests were conducted at soil moisture levels of field capacity (water retention tension of $-6 \mathrm{kPa}$ ), which is important if the pasture is irrigated.

Table 4. Dry matter yield of Brachiaria decumbens cv. Basilisk fertilized with increasing nitrogen doses, regression equation, coefficients of determination $\left(R^{2}\right)$ and of variation $(C V)$

\begin{tabular}{|c|c|c|c|c|c|c|}
\hline \multicolumn{5}{|c|}{ Nitrogen doses $\left(\mathrm{kg} \mathrm{ha}^{-1}\right)$} & \multirow{2}{*}{$\mathbf{R}^{2}$} & \multirow{2}{*}{ CV } \\
\hline $\mathbf{0}$ & 50 & 100 & 150 & 200 & & \\
\hline \multicolumn{5}{|c|}{ Dry matter yield $\left(\mathrm{kg} \mathrm{ha}^{-1}\right.$ year $\left.^{-1}\right)$} & & \multirow{2}{*}{$\begin{array}{c}\% \\
17.61\end{array}$} \\
\hline $2,594.12$ & $3,442.73$ & $4,283.68$ & $4,640.30$ & $5,009.90$ & & \\
\hline \multicolumn{4}{|c|}{$\hat{y}=2,788.32+24.1165^{* *} \mathrm{~N}$} & \multicolumn{3}{|c|}{0.82} \\
\hline
\end{tabular}

$* * * 0.01)$

Table 5. Chemical characteristics of soil from the 0-10 cm layer treated with the different $\mathrm{N}$ doses at the end of the second growing season

\begin{tabular}{|c|c|c|c|c|c|c|c|c|c|c|c|c|c|}
\hline N dose & $\mathbf{p H}$ & OM & $\mathbf{P}$ & $\mathbf{K}$ & $\mathrm{Ca}^{2+}$ & $\mathrm{Mg}^{2+}$ & $\mathrm{Al}^{3+}$ & $\mathrm{H}+\mathrm{Al}$ & SB & $\mathbf{t}$ & $\mathbf{T}$ & $\mathrm{V}$ & m \\
\hline $\mathrm{kg} \mathrm{ha}^{-1}$ year $^{-1}$ & & dag $\mathrm{kg}^{-1}$ & $-\mathrm{n}$ & $\mathrm{m}^{-3}$ & & & & $\mathrm{~mol}_{\mathrm{c}} \mathrm{dm}$ & & & & & \\
\hline 0 & 5.7 & 1.8 & 3.11 & 217.6 & 1.1 & 0.7 & 0.40 & 5.8 & 2.63 & 2.76 & 8.16 & 29 & 14 \\
\hline 25 & 5.0 & 2.0 & 3.45 & 172.3 & 1.1 & 0.4 & 0.76 & 8.1 & 1.94 & 2.70 & 10.00 & 19 & 28 \\
\hline 50 & 4.9 & 2.0 & 3.07 & 117.9 & 0.9 & 0.4 & 1.28 & 10.2 & 1.60 & 2.88 & 11.80 & 14 & 44 \\
\hline 75 & 4.9 & 1.7 & 2.01 & 126.9 & 0.8 & 0.4 & 1.20 & 8.1 & 1.53 & 2.73 & 9.63 & 16 & 44 \\
\hline 100 & 4.8 & 2.0 & 2.92 & 99.7 & 1.0 & 0.4 & 1.26 & 7.3 & 1.66 & 2.82 & 8.96 & 19 & 41 \\
\hline
\end{tabular}


Table 6. Pre-consolidation pressure ( $\sigma p)$, initial soil bulk density (Bd), total pore volume (TPV) and void index (Vd) for five nitrogen doses $(\mathrm{N})$ at three sampling times $(\mathrm{T})$ in the two layers

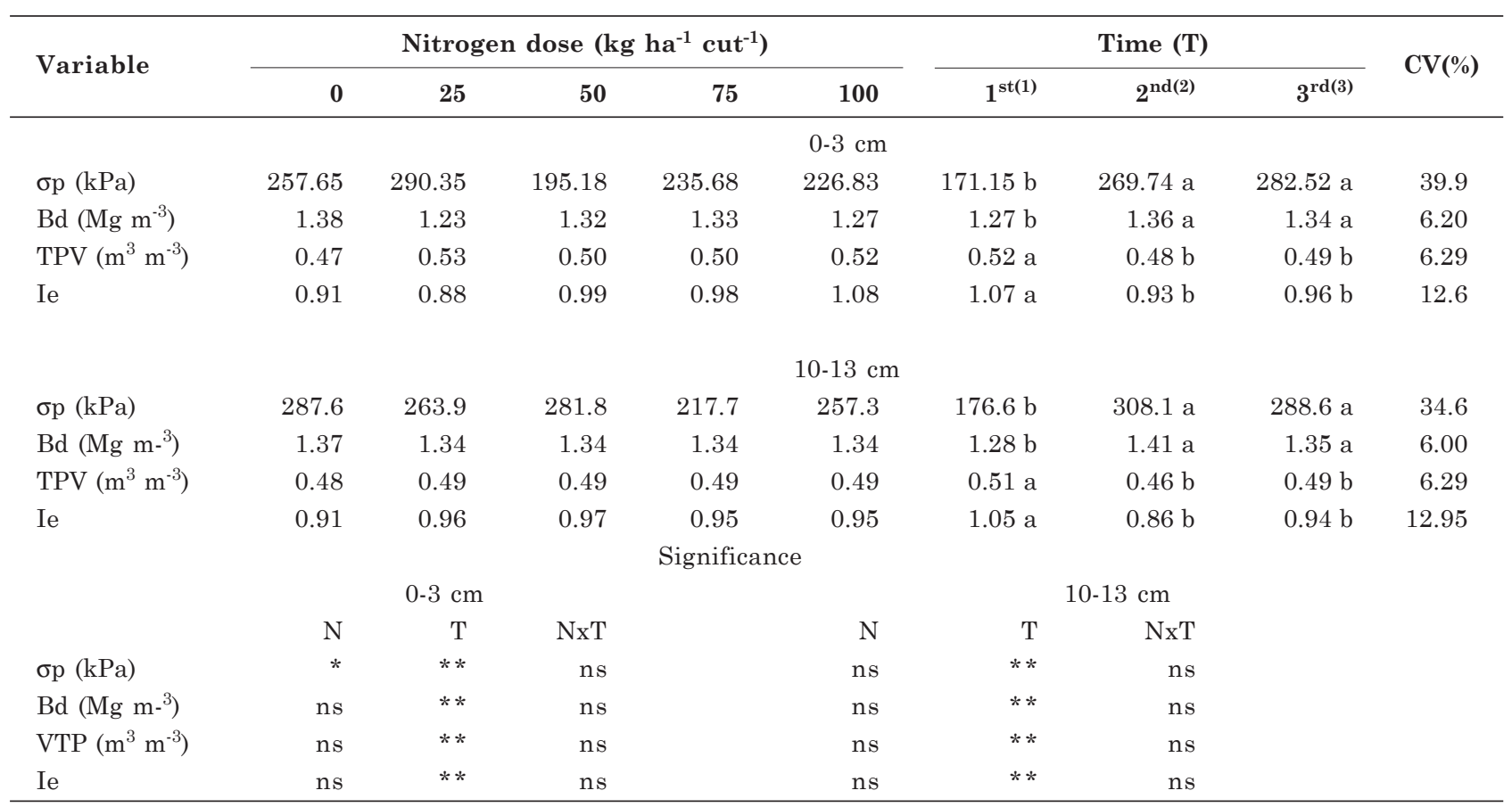

(1) First evaluation: sampling prior to the experiment; ${ }^{(2)}$ second evaluation: sampling at the end of the first growing season; ${ }^{(3)}$ third evaluation: sampling at the end of the second growing season. * $(p<0.05) ; * *(p<0.01)$; ns: not significant.

The increase in pre-consolidation pressure $(\sigma p)$ may be related to the application of $\mathrm{N}$ and/or $\mathrm{P}$ fertilizer. In fact, according to Santos et al. (2002), P plays an important role in promoting the growth of the root system and in the tillering of grasses, thereby increasing productivity. Working with Brachiaria brizantha, Cecato et al. (2000) observed a positive interaction between $\mathrm{N}$ and $\mathrm{P}$ on the production of forage plants and found that $\mathrm{P}$ was associated with increased production and root volume.

Although the native woodland did not receive the same treatments as the experimental area, the óp in the experimental area and native woodland soil was very similar (171.15 and $172.00 \mathrm{kPa}$, respectively), at field capacity moisture $(-6 \mathrm{kPa})$ (Figure 1).

The increase in pre-consolidation pressure $(\sigma p)$ can also be related to the resting period of the soil during which no animal trampling occurred. In the literature, there are indications that animals can exert pressures on the soil on the order of 350 to $400 \mathrm{kPa}$ (Proffitt et al., 1993; Betteridge et al., 1999); therefore, if soil compression tests indicate lower pressures than these, grazing should be delayed when soil moisture is high or permitted only for lighter animals, until soil moisture decreases.

The root system of grasses, which penetrates large volumes of soil, is concentrated for the most part in the top $20 \mathrm{~cm}$ of the soil, where the roots can lessen the pressure applied to the soil and alter the preconsolidation pressure $(\sigma p)$ of the soil.
The values of initial soil bulk density (Bd) (Table 6) in the $0-3 \mathrm{~cm}$ layer were 1.36 and $1.34 \mathrm{Mg} \mathrm{m}^{-3}$ in the second and third evaluation, respectively; these values were not different from each other, but higher than in the first evaluation $\left(1.27 \mathrm{Mg} \mathrm{m}^{-3}\right)$. In the layer 10 $13 \mathrm{~cm}$, the behavior of $\mathrm{Bd}$ was consistent (1.41 and $1.35 \mathrm{Mg} \mathrm{m}^{-3}$ in the second and third evaluation, respectively); these values did not differ, but were higher than in the first time assessment $\left(1.28 \mathrm{Mg} \mathrm{m}^{-3}\right)$. These results were consistent with the preconsolidation pressures (óp), since, according to Guérif (1994), increases in Bd lead to increased frictional forces, more contact points between the particles and a lower capacity for soil movement. Under these conditions, the increased resistance to soil deformation results in an increased load-bearing capacity of the soil. These results demonstrated that Bd influences the load-bearing capacity of the soil.

The total pore volume (TPV) behaved contrary to $\mathrm{Bd}$ at both depths; this finding further explains the behavior of the soil, as, with increasing $\mathrm{Bd}$, particles of clay, silt and sand tend to occupy the pore spaces and reduce TPV. The soil of this study was not compacted, as the values found ranged from 0.48 to $0.52 \mathrm{~m}^{3} \mathrm{~m}^{-3}$ in the layer $0-3 \mathrm{~cm}$ and from 0.46 to $0.51 \mathrm{~m}^{3} \mathrm{~m}^{-3}$ in the layer $10-13 \mathrm{~cm}$, indicating absence of soil compaction (Table 6). Carvalho et al. (2010), working with a Red Latosol pasture cultivated with Brachiaria brizantha cv MG-5 Vitória under animal trampling, obtained a TPV value of $0.48 \mathrm{~m}^{3} \mathrm{~m}^{-3}$, indicating absence of compaction. 


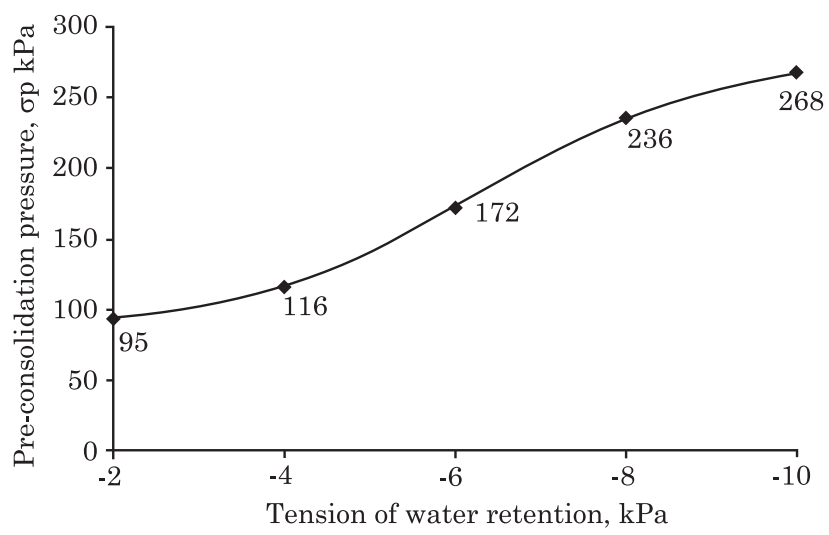

Figure 1. Pre-consolidation pressure as a function of the tension of water retention.

Soil density and porosity have been widely used in the compaction-related studies because these variables are easily measured and minimally affected by water content at the time of soil sampling. According to Genro Junior et al. (2004), the increase in density observed in this case may be normal and harmless, as the pasture productivity was not affected. This finding may be related to the greater pore continuity and the presence of biological pores.

The void index (Vd) was also affected by the sampling time ( 0.93 and 0.96 in the second and third evaluation, respectively); these values did not differ, but were lower than in the first evaluation (1.07) in the $0-3 \mathrm{~cm}$ layer. In the $10-13 \mathrm{~cm}$ layer, the behavior of Ie was similar (0.86 and 0.94 in the second and third evaluation, respectively); these values did not differ, but were lower than in the first evaluation (1.05). The void index is the ratio of the void volume $(\mathrm{Vv})$ by the volume of solids ( $\mathrm{Vs}$ ) in an equal volume of soil. This index is designed to measure the variation in soil volume over time; therefore, if the volume of solids remains constant over time, any change will be measured by a volumetric change in the void content that can result in tensions and deformations in the soil. As the void index increases, the soil porosity increases and the bulk density decreases.

\section{CONCLUSIONS}

1. The increased pre-consolidation pressure (óp) associated with the initial soil bulk density, the total pore volume and the void index indicated that the soil was not compacted and that the load support capacity of the soil increased.

2. Fertilizer management and pasture resting periods improved the conditions for plant development, resulting in a higher dry matter yield.

3 . Results of the pre-consolidation pressure can serve as parameters to determine the stocking rate and time the animals enter the pasture to avoid additional soil compaction.

\section{LITERATURE CITED}

BETTERIDGE, K.; MACKAY, A.D.; SHEPHERD, T.G.; BARKER, D.J.; BUDDING, P.J.; DEVANTIER, B.P. \& COSTALL, D.A. Effect of cattle and sheep treading on surface configuration of a sedimentary hill soil. Aust. J. Soil, 37:743-760, 1999.

CARVALHO, R.C.R.; ROCHA, W.W.; PINTO, J.C.; PIRES, B.S.; DIAS JUNIOR, M.S. \& NUNES, A.H.B. Soil shear strength under non-irrigated and irrigated short duration grazing systems. R. Bras. Ci. Solo, 34:631-638, 2010.

CASAGRANDE, A. The determination of the pre-consolidation load and its pratical significance. In: CONFERENCE ON SOIL MECHANICS AND FOUNDATION ENGINEERING, 1936, Cambridge. Proceedings... Cambridge, ICSMFE, 1936. v.3. p.60-64.

CECATO, U.; YANAKA, F.Y.; BRITO FILHO, M.R.T.; SANTOS, G.T.S.; CANTO, M.W.; ONORATO, W.M. \& PERNELLI, M. Influência da adubação nitrogenada e fosfatada na produção, na rebrota e no perfilhamento do capimmarandú (Brachiaria brizantha [Hochst] stapf. Cv. Marandu). Acta Sci., 22:817-822, 2000.

COSTA, C.; MEIRELLES, P.R.L.; SILVA, J.J. \& FACTORI, M.A. Evolução das pastagens cultivadas e do efetivo bovino no Brasil. R. Veter. Zootec., 15:8-17, 2008.

DIAS JUNIOR, M.S. Compression of three soils under longterm tillage and wheel traffic. East Lansing, Michigan State University, East Lansing, 1994. 114p. (Tese de Doutorado)

DIAS JUNIOR, M.S. \& PIERCE, F.J. A simple procedure for estimating preconsolidation pressure from soil compression curves. Soil Technol., 8:139-151, 1995.

DIAS JUNIOR, M.S. \& PIERCE, F.J. O processo de compactação do solo e sua modelagem. R. Bras. Ci. Solo, 20:175-182, 1996.

EMPRESA BRASILEIRA DE PESQUISA AGROPECUÁRIA . EMBRAPA. Centro Nacional de Pesquisa de Solos. Manual de métodos de análise do solo. 2.ed. Rio de Janeiro, 1997. $212 \mathrm{p}$

EMPRESA BRASILEIRA DE PESQUISA AGROPECUÁRIA EMBRAPA. Centro Nacional de Pesquisa de Solos. Sistema brasileiro de classificação de solos. 2.ed. Rio de Janeiro, 2006. 306p.

GENRO JÚNIOR, S.A.; REINERT, D.J. \& REICHERT, J.M. Variabilidade temporal da resistência à penetração de um Latossolo argiloso sob semeadura direta com rotação de culturas. R. Bras. Ci. Solo, 28:477-484, 2004.

GUÉRIF, J. Effects of compaction on soil strength parameters. In: SOANE, B.D. \& van OUWERKERK, C., eds. Soil compaction in crop production. Amsterdam, Elsevier, 1994. p.191-214.

HOLTZ, R.D. \& KOVACS, W.D. An introduction to geotechnical enginnering. Englewood Cliffs, Prentice-Hall, 1981. 733p. 
IMHOFF, S.; SILVA, A.P. \& TORMENA, C.A. Aplicações de curva de resistência no controle da qualidade física de um solo sob pastagem. Pesq. Agropec. Bras, 35:1493-1500, 2000 .

KONDO, M.K. \& DIAS JUNIOR, M.S. Compressibilidade de três Latossolos em função da umidade e uso. R. Bras. Ci. Solo, 23:211-218, 1999.

MOSADDEGHI, M.R.; KOOLEN, A.J.; HEMMAT, A.; HAJABBASI, M.A. \& LERINK, P. Comparisons or different procedures of pre-compactation stress determination on weakly structure soils. J. Terramec.,44:53-63, 2007.

OLIVEIRA, G.C.; DIAS JUNIOR, M.S.; RESCK, D.V.S. \& CURI, N. Caracterização química e físico-hídrica de um Latossolo Vermelho após vinte anos de manejo e cultivo do solo. R. Bras. Ci. Solo, 28:327-336, 2004.
PIRES, B.S.; DIAS JUNIOR, M.S.; ROCHA, W.W.; ARAUJO JUNIOR, C.F. \& CARVALHO, R.C. Modelos de capacidade de suporte de carga de um Latossolo Vermelho-Amarelo sob diferentes usos e manejos. R. Bras. Ci. Solo, 36:635642, 2012.

PROFFITT, A.P.B.; BENDOTTI, S.; HOWELL, M.R. \& EASTHAM, J. The effect of sheep trampling and grazing on soil physical properties and pasture growth for a RedBrown earth. Aust. J. Agric. Soil Res., 44:317-331, 1993.

SAEG. Sistema para análises estatísticas. Versão 9.1. Viçosa, MG, Fundação Arthur Bernardes/UFV, 2007.

SANTOS, H.Q.; FONSECA, D.M.; CANTARUTTI, R.B.; ALVAREZ V., V.H. \& NASCIMENTO JÚNIOR, D. Níveis críticos de fósforo no solo e na planta para gramíneas forrageiras tropicais, em diferentes idades. R. Bras. Ci. Solo, 26:173-182, 2002. 